\title{
Maxillofacial trauma in a public hospital in Central Brazil: A retrospective study of 405 patients
}

\author{
Guilherme Romano Scartezini ${ }^{a}$, Orlando Aguirre Guedes ${ }^{b}$, Ana Helena Gonçalves de Alencar ${ }^{a}$, \\ Cyntia Rodrigues de Araújo Estrelab ${ }^{\mathrm{b}}$ Carlos Estrela ${ }^{\mathrm{a}}$
}

\begin{abstract}
OBJECTIVE: To evaluate epidemiological aspects of maxillofacial injuries in hospitalized patients. METHODS: The sample was composed of 405 patients treated at the Department of Oral and Maxillofacial Surgery of the Emergency Hospital of Aparecida de Goiânia, Brazil, between 2011 and 2013. The following informations were collected from the patients' medical records: gender, age, cause of injury, seasonal distribution and type of injury. The statistical treatment analyzed data from frequency distribution and chi-squared test. The level of significance was set at $5 \%$ for all analyses. RESULTS: A higher occurrence of maxillofacial injuries was observed in males (72.59\%) and with 21-30 years old (26.17\%). The main etiologic factors involved were vehicle traffic accidents $(30.62 \%)$, falls $(22.72 \%)$ and violence $(21.48 \%)$. The seasonal distribution showed that most cases occurred in autumn (38.02\%), followed by summer (34.07\%). The most common injuries were facial fractures $(80 \%)$, with the nasal bones being the most affected anatomical region (39.75\%). Statistically significant associations between etiological factor, gender and age $(p<0.005)$ were observed.

CONCLUSION: There was a high number of maxillofacial injuries in males aged less than 30 years old due to vehicle traffic accidents.
\end{abstract}

Key words: Maxillofacial injury; Nasal fracture; Epidemiology

\section{Traumatismo bucomaxilofacial em um hospital público do Brasil Central: estudo retrospectivo de 405 pacientes}

\section{RESUMO}

INTRODUÇÃO: Avaliar a epidemiologia dos traumatismos bucomaxilofaciais em pacientes atendidos em um hospital público do Brasil Central.

METODOLOGIA: A amostra do estudo era composta por 405 prontuários de pacientes atendidos no Serviço de Cirurgia e Traumatologia Bucomaxilofacial do Hospital de Urgências de Aparecida de Goiânia, Brasil, entre 2011 e 2013. Os seguintes dados foram coletados dos registros hospitalares: gênero, idade, fator etiológico, data do atendimento e região anatômica. O tratamento estatístico analisou os dados frente à distribuição de frequência e qui-quadrado. O nível de significância foi de $p<0,05$

RESULTADOS: Observou-se elevada frequência de traumatismos bucomaxilofaciais em indivíduos do gênero masculino (72,59\%) e com 21-30 anos (26,17\%). Os principais fatores etiológicos foram os acidentes de trânsito motorizados (30,62\%), quedas (22,72\%) e violência (21,48\%). A distribuição sazonal evidenciou elevado número de traumatismos no outono $(38,02 \%)$ e no verão $(34,07 \%)$. O traumatismo mais comum foi a fratura facial $(80 \%)$, sendo o nariz, a região anatômica mais atingida $(39,75 \%)$. Foram observadas associações significantes entre fator etiológico, gênero e faixa etária $(p<0,005)$.

CONCLUSÃO: Verificou-se elevado número de lesões em indivíduos do gênero masculino, com idade inferior a 30 anos e decorrentes de acidentes de trânsito.

Palavras-chave: Traumatismo bucomaxilofacial; Fratura de nariz; Epidemiologia a Department of Stomatologic Sciences, Federal University of Goiás, Goiânia, GO, Brazil

${ }^{\mathrm{b}}$ Department of Oral Diagnosis, University of Cuiabá, Cuiabá, MT, Brazil 


\section{INTRODUCTION}

Injuries involving the maxillofacial complex represent one of the biggest health problems worldwide [1,2]. Over the past few decades, several studies have reported a significant increase in the incidence of these lesions, with a significant threat to the quality of life of children, adolescents and young adults [3-7], beyond the physical and psychological distress along with the high potential of negative interference in social relations $[1,8,9]$.

Maxillofacial injuries often result in damage to the soft tissues, teeth, and facial bones, including the mandible, maxilla, zygoma, nasoetmoidal complex structures and orbit [4]. These injuries often occur in males aged 20-30 years $[1,7,10,11,12]$. Traffic accidents are presented as the major etiological factors $[1,8,11,13,14]$.

Population studies in Brazil, specifically in regions such as the South, Southeast and Northeast, showed a prevalence ranging from $4.1 \%$ to $32 \%$ of facial trauma $[1,5-7,15,16]$. These vastly differing values reflect cultural differences that include the environment, population behavior or different methodologies employed in collecting data from each study.

In the Midwest, an epidemiological survey performed by Leles et al. [17] demonstrated the facial fracture prevalence of $51 \%$ of the cases evaluated, while a study by Pereira et al. [18] observed 615 facial fractures in 521 records of patients seen in hospital emergency departments.

The planning of public health policies focusing on the prevention of accidents resulting in maxillofacial injuries should be based on regional knowledge of the major risk factors involved. Based on the evidence from the small number of epidemiological studies in the Brazilian population $[1,17,18]$, and considering the specificities and demographic, cultural and socioeconomic differences of each population, this study investigated the epidemiological aspects of maxillofacial trauma in a public hospital in Central Brazil.

\section{METHODS}

This cross-sectional descriptive study was conducted by reviewing the medical records of 405 patients with history of maxillofacial trauma attended at Buccomaxillofacial Surgery and Traumatology Service of the Hospital of Urgency of Aparecida de Goiânia (HUAPA), Aparecida de Goiânia, Goiás, Brazil (latitude 16 49' 23' South, longitude 49 20' 32 " West), from December 2011 to May 2013. Inclusion criteria for this study were the medical records of patients suffering from injuries involving the maxillofacial complex. Excluded were records featuring blank fields and/or data that were not specified.

The following informations were collected from the patients' medical records: gender, age, cause of injury, seasonal distribution and type of injury.

This study was approved by the local Research Ethics Committee (Process \#430.977/2013).
Data were analyzed using the IBM SPSS for Windows 21.0 (IBM Corporation, Somers, NY, EUA), including frequency distribution and cross-tabulation. Chi-square tests were used to compare qualitative data, and the level of statistical significance was set at $5 \%$.

\section{RESULTS}

This study enrolled 405 patients (294 male patients, $72.59 \%$; male-to-female ratio $=2.6: 1$ ), aged 1 to 88 years $($ mean $=26.7$ years, standard deviation $=17.19)$. The highest frequency was in the group of patients aged 21-30 years (26.18\%) (Table 1).

The causes of the injuries were classified into falls (falls from the person's own height or higher), traffic accidents (motorized and bicycle accidents), work accidents, accidents during sports practice, violence (interpersonal aggressions by punching and/or kicking, firearm-related injuries) and other causes. The motorized accidents prevailed, with a rate of $30.61 \%$ of the cases, followed by falls $(22.72 \%)$ and violence (21.48\%) (Table 1).

The fractures were classified according to the bones affected. In the analysis of the 405 files, 324 fractures (80\%) and 54 lacerations $(13,33 \%)$ were found. Injuries involving the nasal bones were the most frequent $(\mathrm{n}=161 ; 39.75 \%)$, followed by fractures of the mandible $(n=61 ; 15.06 \%)$, zygoma $(n=44 ; 10.86 \%)$ and maxilla $(n=30 ; 7.41 \%)$ (Table 1$)$.

The season when most cases occurred was autumn $(\mathrm{n}=154 ; 38.02 \%)$, followed by summer $(\mathrm{n}=138 ; 34.07 \%)$, winter $(n=76 ; 18.77 \%)$ and spring $(n=37 ; 9.14 \%)$.

Statistically significant differences between the etiological factor and the gender and age of the patients (Table 1) were observed. Motorized accident was the main causative factor of injuries among males, accounting for $23.70 \%$ of the lesions, whereas among females, the high number of accidents occurred due to falls $(9.63 \%)$.

Sports and violence caused $34(8.40 \%)$ and $61(15.06 \%)$ injuries in males and $5(1.23 \%)$ and $26(6.42 \%)$ in females, respectively $(\mathrm{p}=0.002)$. Falls were the most common cause of accidents among patients aged 1-10 years $(n=48$, $11.85 \%)$.

The results revealed no statistically significant differences among gender, age and type of injury (Table 2).

\section{DISCUSSION}

Epidemiological studies are essential for making comparisons, monitoring the health status, observing trends in populations/individuals, planning health services, creating educative programs and controlling diseases $[7,14,13,19]$.

In the present study, male patients suffered significantly more injuries than did females [2.6:1]. These findings corroborate the results obtained by Gassner et al. [3], Ribeiro et al. [15], Lin et al. [20], Pereira et al. [18] and van den Bergh et al. [12] that observed male-to-female ratios of 2.1:1, 2.3:1, 3:1, 3.7:1 and 2.4:1, respectively. However, Al Ahmed et al. [21], Motamedi [10] Cavalcanti et al. [6], Jin et al. [2] 
Table 1. Distribution of etiological factors of maxillofacial injuries as a function of age, gender and anatomical region affected.

\begin{tabular}{|c|c|c|c|c|c|c|c|c|}
\hline & \multicolumn{7}{|c|}{ Etiology } & \multirow{3}{*}{$\mathrm{p}^{*}$} \\
\hline & \multirow{2}{*}{$\begin{array}{l}\text { Falls } \\
\text { n (\%) }\end{array}$} & \multicolumn{2}{|c|}{ Traffic Accidents } & \multirow{2}{*}{$\begin{array}{c}\text { Work } \\
\text { accident } \\
\text { n (\%)s }\end{array}$} & \multirow{2}{*}{$\begin{array}{l}\text { Sport } \\
\text { n (\%) }\end{array}$} & \multirow{2}{*}{$\begin{array}{c}\text { Violence } \\
\mathrm{n}(\%)\end{array}$} & \multirow{2}{*}{$\begin{array}{l}\text { Others } \\
\text { n (\%) }\end{array}$} & \\
\hline & & $\begin{array}{c}\text { Motorized } \\
\mathrm{n}(\%)\end{array}$ & $\begin{array}{l}\text { Bicycle } \\
\text { n (\%) }\end{array}$ & & & & & \\
\hline \multicolumn{9}{|l|}{ Age } \\
\hline $1-10$ & $48(11.85)$ & $7(1.73)$ & $2(0.49)$ & $0(0.00)$ & $8(1.98)$ & $4(0.99)$ & $8(1.98)$ & \multirow{7}{*}{0.000} \\
\hline $11-20$ & $8(1.98)$ & $28(6.91)$ & $6(1.48)$ & $1(0.25)$ & $14(3.46)$ & $21(5.19)$ & $4(0.99)$ & \\
\hline $21-30$ & $4(0.99)$ & $46(11.36)$ & $11(2.72)$ & $6(1.48)$ & $12(2.96)$ & $23(5.68)$ & $4(0.99)$ & \\
\hline $31-40$ & $6(1.48)$ & $21(5.19)$ & $4(0.99)$ & $4(0.99)$ & $5(1.23)$ & $20(4.94)$ & $6(1.48)$ & \\
\hline $41-50$ & $11(2.72)$ & $8(1.98)$ & $0(0.00)$ & $2(0.49)$ & $0(0.00)$ & $15(3.70)$ & $0(0.00)$ & \\
\hline $51-60$ & $6(1.48)$ & $6(1.48)$ & $0(0.00)$ & $1(0.25)$ & $0(0.00)$ & $4(0.99)$ & $2(0.49)$ & \\
\hline$>60$ & $9(2.22)$ & $8(1.98)$ & $1(0.25)$ & $0(0.00)$ & $0(0.00)$ & $0(0.00)$ & $1(0.25)$ & \\
\hline \multicolumn{9}{|l|}{ Gender } \\
\hline Male & $53(13.09)$ & $96(23.70)$ & $18(4.44)$ & $14(3.46)$ & $34(8.40)$ & $61(15.06)$ & $18(4.44)$ & \multirow{2}{*}{0.002} \\
\hline Female & $39(9.63)$ & $28(6.91)$ & $6(1.48)$ & $0(0.00)$ & $5(1.23)$ & $26(6.42)$ & $7(1.73)$ & \\
\hline \multicolumn{9}{|l|}{ Type / anatomic region } \\
\hline Nasal bone fracture & $29(7.16)$ & $47(11.60)$ & $10(2.47)$ & $7(1.73)$ & $22(5.43)$ & $38(9.38)$ & $8(1.98)$ & \multirow{9}{*}{0.106} \\
\hline Mandible fracture & $11(2.72)$ & $20(4.94)$ & $4(0.99)$ & $3(0.74)$ & $2(0.49)$ & $17(4.20)$ & $4(0.99)$ & \\
\hline Fracture of maxilla & $6(1.48)$ & $13(3.21)$ & $1(0.25)$ & $1(0.25)$ & $1(0.25)$ & $7(1.73)$ & $1(0.25)$ & \\
\hline Fracture of zygoma & $16(3.95)$ & $8(1.98)$ & $3(0.74)$ & $1(0.25)$ & $5(1.23)$ & $8(1.98)$ & $3(0.74)$ & \\
\hline Fracture of frontal bone & $1(0.25)$ & $2(0,49)$ & $0(0.00)$ & $0(0.00)$ & $2(49)$ & $0(0.00)$ & $0(0.00)$ & \\
\hline Orbital fracture & $4(0.99)$ & $5(1.23)$ & $0(0.00)$ & $0(0.00)$ & $0(0.00)$ & $6(1.48)$ & $2(0.49)$ & \\
\hline Complex fracture face & $0(0.00)$ & $5(1.23)$ & $0(0.00)$ & $0(0.00)$ & $0(0.00)$ & $1(0.25)$ & $0(0.00)$ & \\
\hline Dental trauma & $12(2.96)$ & $8(1.98)$ & $2(0,49)$ & $1(0.25)$ & $3(0.74)$ & $2(0.49)$ & $0(0.00)$ & \\
\hline Laceration & $13(3.21)$ & $16(3.95)$ & $5(1.23)$ & $1(0.25)$ & $4(0.99)$ & $8(1.98)$ & $7(1.73)$ & \\
\hline
\end{tabular}

* Chi-square. $p<0.05$ shows significant difference. $p<0.05$ indicating no significant difference. $n=405$.

Table 2. Distribution of maxillofacial injuries by gender and age group.

\begin{tabular}{|c|c|c|c|c|c|c|c|c|c|c|}
\hline & \multirow[b]{2}{*}{$\begin{array}{l}\text { Dental } \\
\text { trauma } \\
\mathrm{n}(\%)\end{array}$} & \multirow[b]{2}{*}{$\begin{array}{l}\text { Laceration } \\
\text { n (\%) }\end{array}$} & \multicolumn{7}{|c|}{ Type / anatomic region } & \multirow[b]{2}{*}{$p^{*}$} \\
\hline & & & $\begin{array}{c}\text { Complex } \\
\text { fracture face } \\
\mathrm{n}(\%)\end{array}$ & $\begin{array}{l}\text { Frontal } \\
\text { bone } \\
\mathrm{n}(\%)\end{array}$ & $\begin{array}{c}\text { Mandíble } \\
\text { n (\%) }\end{array}$ & $\begin{array}{c}\text { Maxilla } \\
\text { n (\%) }\end{array}$ & $\begin{array}{c}\text { Nasal } \\
\text { bones } \\
\mathrm{n}(\%)\end{array}$ & $\begin{array}{l}\text { Orbital } \\
\mathrm{n}(\%)\end{array}$ & $\begin{array}{c}\text { Zygoma } \\
\text { n (\%) }\end{array}$ & \\
\hline \multicolumn{11}{|l|}{ Gender } \\
\hline Male & $22(5.43)$ & $41(10.12)$ & $4(0.99)$ & $3(0.74)$ & $44(10.86)$ & $22(5.43)$ & $114(28.15)$ & $11(2.72)$ & $33(8.15)$ & \multirow{2}{*}{0.946} \\
\hline Female & $5(1.23)$ & $13(3.21)$ & $2(0.49)$ & $2(0.49)$ & $17(4.20)$ & $8(1.98)$ & $47(11.60)$ & $6(1.48)$ & $11(2.72)$ & \\
\hline \multicolumn{11}{|l|}{ Age } \\
\hline $1-10$ & $11(2.72)$ & $18(4.44)$ & $0(0.00)$ & $1(0.25)$ & $6(1.48)$ & $6(1.48)$ & $24(5.93)$ & $1(0.25)$ & $10(2.47)$ & \multirow{7}{*}{0.085} \\
\hline $11-20$ & $5(1.23)$ & $10(2.47)$ & $2(0.49)$ & $0(0.00)$ & 16 (3.95) & $5(1.23)$ & $32(7.90)$ & $3(0.74)$ & 9 (2.22) & \\
\hline $21-30$ & $7(1.73)$ & $12(2.96)$ & $3(0.74)$ & $1(0.25)$ & $21(5.19)$ & $8(1.98)$ & 41 (10.12) & $4(0.99)$ & $9(2.22)$ & \\
\hline $31-40$ & $3(0.74)$ & $5(1.23)$ & $1(0.25)$ & $2(0.49)$ & $8(1.98)$ & $5(1.23)$ & $34(8.40)$ & $1(0.25)$ & $7(1.73)$ & \\
\hline $41-50$ & $1(0.25)$ & $4(0.99)$ & $0(0.00)$ & $0(0.00)$ & $6(1.48)$ & $4(0.99)$ & $16(3.95)$ & $2(0.49)$ & $3(0.74)$ & \\
\hline $51-60$ & $0(0.00)$ & $2(0.49)$ & $0(0.00)$ & $0(0.00)$ & $3(0.74)$ & $0(0.00)$ & $7(1.73)$ & $4(0.99)$ & $3(0.74)$ & \\
\hline$>60$ & $0(0.00)$ & $3(0.74)$ & $0(0.00)$ & $1(0.25)$ & $1(0.25)$ & $2(0.49)$ & $7(1.73)$ & $2(0.49)$ & $3(0.74)$ & \\
\hline
\end{tabular}

* Chi-square. $p<0.05$ shows significant difference. $p<0.05$ indicating no significant difference. $n=405$.

and Chrcanovic et al. [7] observed higher male-to-female ratios: $11: 1,8,1: 1,8,6: 1,4,6: 1$ and 5.4:1, respectively.

Several factors may influence the relationship between gender and maxillofacial trauma, such as the socioeconomic and cultural characteristics of the sample [1,17]. In general, males are more involved in traffic accidents and physical contact activities without the use of adequate protection [7]. Moreover, they are more exposed to violent interactions [7,9].
Despite the fact that the trend of recent years signals increasing rates of injuries among female subjects due to the increased participation of women in society $[3,5,19]$, this study's results did not reflect this tendency.

In this study, there was a high frequency of injuries in participants aged 21-30 years (26.18\%), which is in agreement with the results obtained in other studies $[3,6,7,17,20-22]$. 
The main etiological factor of maxillofacial injuries observed in the present study sample was motorized accidents (30.61\%), considered an unintentional factor, in agreement with epidemiological surveys conducted in several countries $[1,8,11,13,14]$. Motorized accidents occur mainly due to the carelessness and negligence of drivers, poorly maintained vehicles and roads in poor condition [7]. Furthermore, there is significant reluctance in the use of helmets, speeding, a lack of tolerance and increased competitiveness in traffic among young males [11]. In developed countries, we observe a reduction in the rates of traumatic injuries resulting from motorized accidents. This is due to changes in legislation and the adoption of preventive measures involving the compulsory use of seat belts, the sale of cars with airbags and penalties for drunken driving [12].

The type of trauma most commonly observed in this study was facial fracture $(80 \%)$, a result higher than that of Leles et al. [17] in Brazil (51\%) and of Jin et al. [2] in China (64\%). The studies of Gassner et al. [3] in Austria (62.5\%) and Leles et al. [17] in Brazil (98\%) reported a high proportion of soft tissue injuries. In the present study, the proportion of soft tissue injuries was $13.33 \%$, justified by the fact that only information about lacerations was collected.

The anatomical area with the highest rate of fracture was the nose $(n=161,39.75 \%)$; these findings are similar to the results of Arosarena et al. [23] in Canada. In contrast, Motamedi [10] in Iran, Brasileiro \& Passeri [1] in Brazil and Jin et al. [2] in China observed a high prevalence of mandibular fractures. Among the bones that form the facial skeleton, the nasal bones are those with the least resistance. This characteristic, combined with the relative prominence of the nose, makes this area more susceptible to injury [7,17]. It should be emphasized that the type of damage observed is directly related to the place where the study was developed. Thus, depending on the location of the study, patients with a diagnosis of fracture of the nasal bone are referred for treatment with a plastic surgeon and/or otolaryngologist and not with a maxillofacial surgeon $[8,10,19]$. This fact may explain the low number of nose fractures reported in the existing literature [17]. The HUAPA does not offer plastic surgery and/or otolaryngology services; therefore, all facial trauma is referred to the Service of Oral and Maxillofacial Surgery.

Regarding seasonal variation, the present study's results showed a significant number of accidents in autumn (March to June) (38.02\%) and summer (December-March) (34.07\%). These results are consistent with previous studies conducted in Brazil [5], Austria [3] and the United Kingdom (UK) [4]. In the summer, school holidays occur, which is a period of great opportunity for outdoor sports, recreation and travel by car $[4,6]$. However, these results differ from those of Chrcanovic et al. [7], developed in Brazil, where a high number of injuries were observed in the spring.

Brazil is a tropical country where drastic temperature changes are not observed in most regions during the year. This means that the four seasons are not well defined. Therefore, the comparison between studies conducted in different geographical areas of Brazil and studies conducted in other countries should be made with caution.

Regarding the associations, it was found that the etiologic factors varied according to age group; falls were more frequent among the 1- to 10-year-old patients. These results are consistent with those of Kotecha et al. [4]. For these authors, when a child learns to walk and run, the incidence of falls increases significantly due to the immature development of coordination and mobility. In the present study, with increasing age, motorized accidents and violence constituted the main etiological agents of injuries. One possible explanation is related to the fact that young adults have a higher level of social activity than do children, the middle-aged and the elderly. A retrospective study, developed in a public hospital, also revealed associations among age, traffic accidents and falls, where children and young adults were the main victims [17]. It has been emphasized that the place where the study is conducted and the age group involved in the sample must be given proper consideration during the analysis of the etiological factor of maxillofacial injuries [3].

Epidemiological studies have major advantages, including low cost, high potential descriptive, analytical simplicity and a relatively short duration, thus becoming a viable source for the establishment of hypotheses [24]. Present as one of the limitations is the vulnerability of the databases. The quality of information depends on the accuracy with which the initial examination is performed and on the correct completion of the clinical record. Thus, when any examination or information ceases to be raised during history-taking or is not recorded in the chart, the final study outcome is compromised and/or limited [7]. Another major limitation is the inability to establish the temporal nexus necessary to prove cause and effect, as both are assessed at the same time [25]. In addition, epidemiological studies are unsuitable for studies of rare diseases and incidence [24].

Epidemiological studies involving maxillofacial injury can assist in the development of prevention policies in order to reduce the damage associated with risk groups, especially when considering the associations among age, gender and etiology. Furthermore, future prospective studies are needed, based on the monitoring of treated patients, with the aim of evaluating the therapeutic protocols used, the effectiveness of these actions in society and their implications.

\section{CONCLUSION}

Based on the obtained data, it may be concluded:

A higher prevalence of injuries was found in male patients; the most-affected age group was 21-30 years. Motorized accidents were the main etiological factor, and the most prevalent type of trauma was the fracture, with the most-affected anatomical region being the nose.

Motorized accidents and work accidents, sports and violence were the main etiological factors related to the male, while falls were the most common causes of injuries in females. 
Falls were the most common causes among participants in the age group of 1-10 years, while traffic accidents and violence were more common in the age group of 11-40 years.

\section{REFERENCES}

1. Brasileiro BF, Passeri LA. Epidemiological analysis of maxillofacia fractures in Brazil: a 5-year prospective study. Oral Surg Oral Med Oral Pathol Oral Radiol Endod 2006;102:28-34. https://doi.org/10.1016/j. tripleo.2005.07.023

2. Jin Z, Jiang X, Shang L. Analysis of 627 hospitalized maxillofacial-oral injuries in Xi'an, China. Dent Traumatol 2014;30:147-53. https://doi. org/10.1111/edt.12044

3. Gassner R, Tuli T, Hächl O, Rudisch A, Ulmer H. Craniomaxillofacial trauma: a 10 year review of 9543 cases with 21067 injuries. J Craniomaxillofac Surg 2003;31:51-61. https://doi.org/10.1016/S1010-5182(02)00168-3

4. Kotecha S, Scannell J, Monaghan A, Williams RW. A four year retrospective study of 1062 patients presenting with maxillofacial emergencies at a specialist paediatric hospital. Br J Oral Maxillofac Surg 2008;293-6. https:// doi.org/10.1016/j.bjoms.2007.11.011

5. Scariot R, Oliveira IA, Passeri LA, Rebellato NLB, Müller PR. Maxillofacia injuries in a group of Brazilian subjects under 18 years of age. J Appl Oral Sci 2009; 17:195-8. https://doi.org/10.1590/S1678-77572009000300012

6. Cavalcanti AL, Bezerra PKM, Oliveira DM, Granville-Garcia AF. Maxillofacial injuries and dental trauma in patients aged 19-80 years, Recife, Brazil. Rev Esp Cir Oral Maxilofac 2010;32:11-6. https://doi.org/10.1016/S11300558(10)70026-5

7. Chrcanovic BR, Abreu MHNG, Freire-Maia B, Souza LN. 1,454 mandibular fractures: A 3-year study in a hospital in Belo Horizonte, Brazil. J Craniomaxillofac Surg 2012;40:116-23. https://doi.org/10.1016/j. jcms.2011.03.012

8. Lee KH, Snape L, Steenberg LJ, Worthington J. Comparison between interpersonal violence and motor vehicle accidents in the etiology of maxillofacial fractures. ANZ J Surg 2007:77:695-8. https://doi.org/10.1111/ j.1445-2197.2007.04189.x

9. Kostakis G, Stathopoulos P, Dais P, Gkinis G, Igoumenakis D, Mezitis $\mathrm{M}$, et al. An epidemiologic analysis of 1142 maxillofacial fractures and concomitant injuries. Oral Surg Oral Med Oral Pathol Oral Radiol 2012; 114:S69-73. https://doi.org/10.1016/j.tripleo.2011.08.029

10. Motamedi MHK. An assessment of maxillofacial fractures: a 5-year study of 237 patients. J Oral Maxillofac Surg 2003; 61:61-4. https://doi. org/10.1053/joms.2003.50049

11. Subhashraj K, Nandakumar N, Ravindran C. Review of maxillofacial injuries in Chennai, India: a study of 2748 cases. Br J Oral Maxillofac Surg 2007;45:637-9. https://doi.org/10.1016/j.bjoms.2007.03.012
12. van den Bergh B, Karagozoglu KH, Heymans MW, Forouzanfar T. Aetiology and incidence of maxcillofacial trauma in Amsterdam: a retrospective analysis of 579 patients. J Craniomaxillofac Surg 2012;40:165-9. https:// doi.org/10.1016/j.jcms.2011.08.006

13. Hogg NJ, Stewart TC, Armstrong JE, Girotti MJ. Epidemiology of maxillofacial injuries at trauma hospital in Ontario, Canada between 1992 and 1997. J Trauma 2000;49:425:32

14. lida S, Kogo M, Sugiura T, Mima T, Matsuya T. Retrospective analysis of 1502 patients with facial fractures. Int J Oral Maxillofac Surg 2001;30:286-90. https://doi.org/10.1054/ijom.2001.0056

15. Ribeiro MFP, Marcenes W, Croucher R, Sheiham A. The prevalence and causes of maxillofacial fractures in patients attending accident and emergency departments in Recife-Brazil. Int Dent J 2004;54:47-51. https:// doi.org/10.1111/j.1875-595X.2004.tb00252.x

16. Maliska MCS, Júnior SML, Gil JN. Analysis of 185 maxillofacial fractures in the state of Santa Catarina, Brazil. Braz Oral Res 2009;23:268-74. https:// doi.org/10.1590/S1806-83242009000300008

17. Leles JLR, Santos ÊJ, Jorge FD, Silva ET, Leles CR. Risk factors for maxillofacial injuries in a Brazilian emergency hospital sample. J Appl Oral Sci 2010;18:23-9. https://doi.org/10.1590/S1678-77572010000100006

18. Pereira CM, Filho MS, Carneiro DS, Arcanjo RC, Andrade LA, Araújo MGB Epidemiology of maxillofacial injuries at a regional hospital in Goiânia Brazil, between 2008 and 2010. RSBO 2011;8:381-5.

19. Roccia F, Bianchi F, Zavattero E, Tanteri G, Ramieri. Characteristics of maxillofacial trauma in females: a retrospective analysis of 367 patients J Craniomaxillofac Surg 2010;38:314-9. https://doi.org/10.1016/j. jcms.2009.10.002

20. Lin S, Levin L, Goldman S, Peled M. Dento-alveolar and maxillofacial injuries - a retrospective study from a level 1 trauma center in Israel. Dent Traumatol 2007;23:155-7. https://doi.org/10.1111/j.1600-9657. 2005.00418.x

21. Al Ahmed HEA, Jaber MA, Fanas SHA, Karas M. The pattern of maxillofacial fractures in Sharjah, United Arab Emirates: A review of 230 cases. Ora Surg Oral Med Oral Pathol Oral Radiol Endod 2004;98:166-70. https://doi. org/10.1016/j.tripleo.2004.01.020

22. Yokoyama T, Motozawa Y, Sasaki T, Hitosugi M. A retrospective analysis of oral and maxillofacial injuries in motor vehicle accidents. J Oral Maxillofac Surg 2006;64:1731-35. https://doi.org/10.1016/j.joms.2005.11.104

23. Arosarena OA, Fritsch TA, Hsueh Y, Aynehchi B, Haug R. Maxillofacial injuries and violence against women. Arch Facial Plast Surg 2009; 11:48-52. https://doi.org/10.1001/archfacial.2008.507

24. Almeida-Filho N, Rouquayrol MZ. Introdução à epidemiologia. 3a ed. Rio de Janeiro: Medsi, 2002.

25. Freire MCM, Pattusi MP. Tipos de estudo. In: Estrela C. Metodologia Científica. $2^{a}$ ed. São Paulo: Artes Médicas, 2005. p. 185-209. 